\title{
MENAKAR KASUS PENYALAHGUNAAN NARKOBA OLEH KELOMPOK MAHASISWA FIB USU DENGAN TEORI-TEORI KRIMINOLOGI
}

\author{
Rafsanjani Is Marus* \\ "Politeknik Imigrasi \\ Email: rafsanjaniismarus@gmail.com
}

\begin{abstract}
Abstrak:
Tujuan dari penelitian ini adalah untuk mengetahui sebab kelompok mahasiswa FIB USU dapat terjerumus kepada praktek penyalahgunaan narkoba dan bagaimana kasus tersebut dipahami melalui teori-teori kriminologi. Untuk mengetahui hal tersebut peneliti melakukan penelitian dengan metode normatif. Teknik pengumpulan data dengan cara kajian dan riset kepustakaan. Hasil dari pengumpulan data kemudian dianalisis secara kualitatif dan dihubungkan dengan teori-teori kriminologi yang berkembang. Hasil dari penelitian ini menunjukan bahwa Social Learning, Labeling, Differential Association, dan Anomie /Strain Theory merupakan pendekatan yang kuat dan konsisten dari kemungkinan perilaku penggunaan narkoba mahasiswa. Analisis ini juga menjabarkan sebab penggunaan narkoba para mahasiswa FIB USU tersebut dengan teori modern tentang perilaku menyimpang (deviant) dalam perilaku penggunaan narkoba pelajar zaman sekarang. Sehingga diharapkan kedepannya para kriminolog menemukan pendekatan yang lebih interdisiplin untuk kasus penyalahgunaan narkoba pada generasi muda di masa depan.
\end{abstract}

\section{Kata kunci: Kriminologi; Penyalahgunaan Narkoba; Teori}

\section{Abstract:}

This research aims to find out why the University of Northern Sumatra student group can fall into the practice of drug abuse and how the case is understood through criminological theories. For the purpose of this study, the following research was extracted using the normative method. Data collection techniques by means of literature studies and research. The data obtained through library research were then analyzed qualitatively and linked to criminological theories. The results of this study indicate that Social Learning, Labeling, Differential Association, and Anomie or Strain Theory are strong and consistent approaches to the possibility of student drug use behavior. This research also describes the reasons for the drug use of the University of Northern Sumatra students with modern theories about deviants. So it is hoped that in the future, criminologists will find a more 
interdisciplinary approach to drug abuse cases in the younger generation in the future.

\section{Keywords : Criminology; Drug Abuse; Theory}

\section{PENDAHULUAN}

Kasus penyalahgunaan narkoba semakin marak terjadi tidak hanya di kotakota besar, namun telah menjangkau kota-kota kecil di berbagai wilayah Indonesia. Tindakan kejahatan ini telah menjamah berbagai lapisan masyarakat dari tingkat sosial ekonomi menengah bawah sampai tingkat sosial ekonomi atas. Perkembangan teknologi informasi dan faktor globalisasi merupakan pemicu terjadinya perluasan dan peningkatan kasus narkoba di Indonesia. Pada masa sekarang, internet membuat komunikasi antar pengguna, pengedar, pemasok dapat semakin mudah dan cepat. Tercatat pada bulan Oktober 2021 ini, Badan Narkotika Nasional (BNN) telah menangani kasus Narkotika di Indonesia sebanyak 6.128 juta kasus. Berdasarkan peta pergerakan narkoba dunia yang dirilis oleh UNODC, posisi Indonesia yang dulunya berstatus 'negara transit' kini menjadi 'negara tujuan' perdagangan narkoba illegal. ${ }^{1}$ Fakta ini kemudian menunjukkan bahwa masyarakat Indonesia tidak kebal dari cengkeraman penggunaan narkoba. Penduduk Indonesia yang lebih muda dilaporkan menyalahgunakan narkoba lebih banyak daripada orang dewasa.

Pengurus Dewan Pengurus Pusat (DPP) Aliansi Relawan Perguruan Tinggi Anti Penyalahgunaan Narkoba (Artipena) menyampaikan dalam acara diskusi Hari Anti Narkotika Internasional (HANI) 2021 bahwa 27\% pengguna narkoba di Indonesia berasal dari kalangan pelajar dan mahasiswa. ${ }^{2}$ Lembaga pendidikan yang seharusnya menjadi tempat yang bersih dan bebas dari praktek-praktek kejahatan, dewasa ini peredaran narkoba telah masuk kedalam lingkungan pendidikan seperti sekolah dan kampus. Dalam usia yang produktif dan labil, para pelajar dan mahasiswa sangat rentan terpengaruh dengan tren perkembangan zaman. Rasa ingin tahu yang tinggi serta faktor lingkungan dan pergaulan yang buruk membuat mereka lebih gampang terpengaruh untuk menggunakan narkoba. Hal ini senada dengan data BNN yang mengatakan bahwa $17 \%$ dari total pengguna narkoba adalah mahasiswa atau terdapat sekitar 1,2 juta mahasiswa yang menggunakan narkoba. ${ }^{3}$

Data yang dikeluarkan BNN ini tentunya sangat memprihatinkan dikarenakan mahasiswa merupakan penerus tonggak kepemimpinan negara. Bagaimana nasib

\footnotetext{
1 Valentina Lusia Sinta Herindrasti, "Drug-Free ASEAN 2025: Tantangan Indonesia Dalam Penanggulangan Penyalahgunaan Narkoba," Jurnal Hubungan Internasional 7, no. 1 (2018).

2 https://www.beritasatu.com/nasional/792291/27-pengguna-narkoba-dari-kalangan-pelajar-danmahasiswa, diakses pada hari Senin (25/09/21) pada pukul 10.00 WIT

3 https://puslitdatin.bnn.go.id/portfolio/data-statistik-kasus-narkoba/, diakses pada hari Senin (25/09/21) pada pukul 10.42 WIT
}

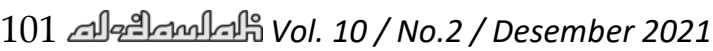


negara Indonesia apabila banyak penerusnya terlibat kasus penyalahgunaan narkoba. Oleh karena itu, berangkat dari asumsi penulis terkait penyalahgunaan narkoba dengan bentuk kejahatan di masyarakat, maka hal ini perlu dikaji secara kriminologis. Tulisan ini dibuat untuk memahami penyalahgunaan narkoba di kalangan mahasiswa dengan mengintegrasikan fakta-fakta dalam berita dan teori-teori kriminologi modern.

\section{Landasan Teori: Narkoba, Kejahatan, dan Remaja}

Teori kriminologi adalah teori tentang sifat, tingkatan, penyebab dan pengendalian pelaku criminal, yang jenis utamanya adalah teori biologis, psikologis, dan sosiologis serta teori individu tertentu ${ }^{4}$ seperti teori pilihan rasional. Teori kriminologi dibuat agar kita dapat lebih memahami mengapa orang berperilaku seperti itu dan bahwa dalam memahami alasannya, kita dapat merespons tindakan ini secara lebih efektif. dan aktor yang melakukan tindakan tersebut ${ }^{5}$. Sebagian orang yang mempelajari tentang kriminologi pasti menyadari adanya hubungan antara narkoba dan sebab kejahatan tertentu. Telah banyak kasus yang membuktikan bahwa mayoritas pelaku kejahatan serius setidaknya dibawah pengaruh alkohol atau penyalahgunaan narkoba dalam melakukan kejahatan tersebut.

Dalam tulisan ini ada banyak perdebatan mengenai dinamika hubungan narkoba dan kejahatan (tindakan kriminal). Tiga penjelasan untuk hubungan tersebut antara lain: ${ }^{6}$ (a) penggunaan narkoba mengarah pada kejahatan, (b) kejahatan mengarah pada penggunaan narkoba, dan (c) hubungan narkoba/kejahatan dijelaskan oleh serangkaian penyebab umum. Pernyataan tersebut kemudian diperkuat dengan data dari UNODC, terdapat hubungan erat antara penyalahgunaan narkoba dan kejahatan. Para pengguna narkoba melakukan kejahatan untuk membayar narkoba mereka dan ini menimbulkan kerugian bagi masyarakat. Selain itu, banyak penjahat berada di bawah pengaruh obat-obatan saat melakukan kejahatan. ${ }^{7}$ Hal-hal seperti ini akan menjadi kebiasaan dan mempengaruhi pemberantasan kejahatan narkoba akan menjadi sesuatu yang sulit diwujudkan.

Para peneliti yang percaya bahwa penggunaan narkoba mengarah pada kejahatan berasumsi bahwa individu yang menyimpang (deviant) lebih mungkin daripada individu yang tidak menyimpang (non-deviant) untuk menemukan diri mereka dalam situasi sosial di mana penggunaan narkoba didorong dan bahwa keterlibatan dalam subkultur semacam itu memberikan konteks untuk penggunaan

\footnotetext{
${ }^{4}$ (Akers, 1999)

${ }^{5}$ Dan Okada, "Criminological Theory and Crime Explanation," Criminal Justice and Criminological Paradigms (2015).

${ }^{6}$ D. M. Gorman, "Etiological Theories and the Primary Prevention of Drug Use," Journal of Drug Issues, 1996.

7 World Drug Report 2012. USA: United Nations Office On Drugs And Crime; 2012. Available from: http://www.unodc.org/unodc/en/data-and-analysis/WDR-2012.html, diakses pada hari Senin (25/09/21) pada pukul 07.31 WIT
}

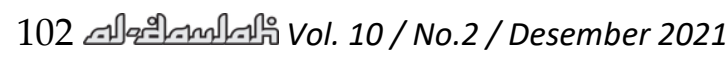


narkoba ${ }^{8}$. Selain itu, beberapa peneliti mengusulkan bahwa individu yang menyimpang (deviant) dapat menggunakan narkoba sebagai bentuk pengobatan sendiri atau untuk memberikan alasan atas tindakan menyimpang mereka ${ }^{9}$. Pendapat diatas menyimpulkan bahwa para pengguna narkoba umumnya adalah individu yang secara sosial menyimpang dari subkultur atau kebiasaan masyarakat yang normal.

Penjelasan penyebab umum dari hubungan narkoba dan kejahatan menyatakan bahwa penggunaan narkoba dan kejahatan tidak memiliki hubungan sebab akibat langsung tetapi terikat oleh sejumlah penyebab umum. Penyebab umum ini termasuk sifat genetik atau temperamental, gangguan kepribadian antisosial, alkoholisme, dan hubungan yang buruk dengan orang tua ${ }^{10}$. Norma subkultur yang mempromosikan perilaku "jalanan" (street behavior), juga dapat memperkuat perilaku kriminal dan penggunaan narkoba. ${ }^{11}$ Penjelasan tambahan termasuk penyebab lingkungan, seperti lingkungan miskin, padat penduduk yang kekurangan modal sosial dan penyebab situasional seperti bar dan acara olahraga di mana ada peningkatan jumlah pelanggar yang termotivasi dan target yang sesuai (suitable target) ${ }^{12}$. Dengan kata lain, interaksi sosial antar individu menghasilkan proses pembelajaran dan mencerminkan sifat dari apa yang dipelajari tersebut melalui pengamatan lingkungan serta proses sosialisasi individu tersebut. Oleh karena itu, dalam situasi atau lingkungan tertentu, kejahatan narkoba merupakan perilaku normatif dan sudah biasa.

Akhirnya menurut penulis, kasus penyalahgunaan narkoba oleh masyarakat khususnya pada remaja atau pelajar tidak terlepas dari lingkungan sosial dan nonsosial (individu) yang cukup besar. Banyak individu, terutama pelajar dan mahasiswa menggunakan narkoba hanya karena mereka menganggap teman-teman mereka cenderung melakukan hal yang sama. Jika seorang remaja merasakan respon yang baik dari teman sebaya untuk penggunaan narkoba, maka mereka lebih

8 P. M. Collins, J. J., \& Messerschmidt, "Epidemiology of Alcohol-Related Violence," Alcohol Health \& Research World 17, no. 2 (1993): 93-100; H. R White, "The Drug Use-Delinquency Connection in Adolescence," in 1990 (Academy of Criminal Justice Sciences: Anderson Publishing Co., 1990), 215-256. ${ }^{9}$ E. J. Khantzian, "The Self Medication Hypothesis of Addictive Disorders: Focus on Heroin and Cocaine Dependence," American Journal of Psychiatry, 1985.

${ }^{10}$ H. R. White, J. Brick, and S. Hansell, "A Longitudinal Investigation of Alcohol Use and Aggression in Adolescence," in Journal of Studies on Alcohol, vol. 54, 1993.

${ }^{11}$ Loc. Cit., Gorman, D. M., \& White, H. R. (1995). hal 73.

${ }^{12}$ Margaret E. Ensminger, James C. Anthony, and Joan McCord, "The Inner City and Drug Use: Initial Findings from an Epidemiological Study," Drug and Alcohol Dependence 48, no. 3 (1997); J. Fagan, "Set and Setting Revisited: Influences of Alcohol and Illicit Drugs on the Social Context of Violent Events.," Alcohol and interpersonal violence: fostering multidisciplinary perspectives 24 (1993): 161-191; Robert J. Sampson, Stephen W. Raudenbush, and Felton Earls, "Neighborhoods and Violent Crime: A Multilevel Study of Collective Efficacy," Science 277, no. 5328 (1997); Josefina Figueira-McDonough, " Disorder and Decline: Crime and the Spiral of Decay in American Neighborhoods. Wesley G. Skogan ," Social Service Review 66, no. 2 (1992). 
mungkin untuk terlibat dalam perilaku tersebut. Berdasarkan hubungan kejahatan dan narkoba dengan pendekatan kriminologi diatas didapatkan bahwa differential association dan social learning theory telah menunjukkan bahwa individu bahkan tidak perlu mengamati kenakalan secara langsung melainkan melihat bahwa perilaku tersebut akan mendapatkan persetujuan teman sebaya. Secara keseluruhan, tulisan ini berusaha menunjukkan bahwa teori-teori kriminologi dapat digunakan dalam mengkaji berbagai perilaku menyimpang atau kejahatan di masyarakat termasuk penyalahgunaan narkoba.

\section{METODE PENELITIAN}

Penelitian ini menggunakan metode penelitian kualitatif dengan analisis kepustakaan. Pengumpulan data dalam penelitian ini menggunakan Teknik library research berupa buku-buku, berita, dan publikasi ilmiah di internet. Penelitian ini secara deskriptif bermaksud menjabarkan hasil kajian mendalam terkait studi kasus dengan menggunakan pendekatan dan teori-teori kriminologi yang berkembang. Dilihat dari sifatnya, penelitian ini bersifat evaluatif dikarenakan maksud dari penelitian ini adalah memberikan analisis yang mendalam terhadap teori kriminologi yang relevan dipakai pada studi kasus tersebut.

\section{HASIL PENELITIAN DAN PEMBAHASAN}

\section{Studi Kasus: Puluhan Mahasiswa FIB USU Ditangkap BNN di Kampus}

Dewasa ini banyak kasus-kasus narkoba baik pengedaran maupun penyalahgunaan narkoba di kalangan mahasiswa Indonesia. Adapun contoh kasus penyalahgunaan narkoba yang dilakukan oleh mahasiswa terjadi di Medan, Sumatera Utara. Pada tanggal 10 Oktober 2021, BNN Provinsi Sumatera Utara melaksanakan razia di kawasan Kampus Universitas Sumatera Utara (USU). Dalam operasi razia tersebut, BNNP Sumut berhasil menggerebek dan mengamankan 47 orang dalam kasus narkoba jenis ganja. Diantara 47 orang tersebut, 31 orang terbukti penyalahgunaan narkoba di Kampus USU. Sedangkan 16 orang lagi negative dan tidak terbukti sebagai pemakai narkoba, maka mereka kemudian dibebaskan oleh petugas BNNP Sumut. Kemudian yang menjadi menarik adalah dari jumlah 31 orang yang terbukti, 20 diantaranya adalah mahasiswa aktif dan alumni USU.

Berikut merupakan hasil pendataan latar belakang para mahasiswa tersebut oleh BNNP Sumut, HP (Bahasa Inggris D3-FIB Stambuk 2019, GP (Perjalanan Wisata FIB Stambuk 2019), MH (Perjalanan Wisata FIB Stambuk 2019), AMM (Perjalanan Wisata FIB Stambuk 2021), BP (FISIP) Stambuk 2020, LS (Perjalanan Wisata FIB Stambuk 2020), PS (Etnomusikologi FIB Stambuk 2020), JDS (Perjalanan Wisata FIB Stambuk 2017, ADH (Perjalanan Wisata FIB Stambuk 2016), RHD (Etnomusikologi FIB-Stambuk 2016), AS (Ilmu Sejarah FIB-Stambuk 2015), YK (Etnomusikologi FIBStambuk 2015), GF (Perjalanan Wisata FIB Stambuk 2017), dan FS (Perjalanan Wisata FIB Stambuk 2016), dan WS (Etnomusikologi FIB-Stambuk 2018). Selanjutnya juga 
terdapat Alumni USU yakni FS (Alumni Ilmu Sejarah FIB Stambuk 2013), JS (Alumni Fakultas Hukum Stambuk 2011), S (Perjalanan Wisata FIB Alumni), HMN (Perjalanan Wisata FIB Stambuk 2013 Alumni), dan JS (Alumni FIB). Kemudian juga terdapat 2 orang dari kampus berbeda yakni AS (Mahasiswa Triguna Dharma) dan ES (Mahasiswa Unimed). ${ }^{13}$

Dari pengembangan atas razia narkoba tersebut, BNNP Sumut juga berhasil menangkap dua orang pengedar yakni DM (mahasiswi) dan JHS (mahasiswa). Hal tersebut disampaikan oleh Kepala BNNP Sumut, Brigjen Pol Toga Habinsaran Panjaitan yang didampingi oleh Wakil Rektor I USU, Edy Ikhsan dalam konferensi pers di halaman kantor BNNP Sumut. Dalam konferensi pers tersebut tutut hadir Wakil Rektor V USU, Luhut Sihombing dan Kepala Humas USU, Amalia Meutya mengingat objek pada kasus tersebut adalah mahasiswa aktif USU. ${ }^{14}$ Kepala BNNP Sumut menyampaikan bahwa razia tersebut dilakukan karena adanya informasi dari masyarakat sekitar yang kemudian dikoordinasikan dengan pihak rektorat USU. Razia yang dilakukan pada malam minggu sekitar pukul 23.00 WIB di FIB USU tersebut kemudian setelah dilakukan penggeledahan, BNNP Sumut menemukan barang bukti jenis ganja berjumlah 118 paket kecil yang sudah siap pakai dan ukuran besar sekitar 1.8 gram.

Total barang bukti yang diamankan pada razia tersebut sebanyak 508,6 gram yang mana 256 gram merupakan milik tersangka pengedar dengan inisial JHS. Atas barang bukti permulaan ini, BNNP Sumut kemudian melakukan interogasi dan pengembangan lebih lanjut. Hasilnya pada 10 Oktober 2021, BNNP Sumut kembali menangkap dua orang pengedar dan perantara yakni DM dan FAY di jalan cemara, kecamatan Medan Kota. Selanjutnya, pihak BNNP Sumut masih melakukan penyelidikan dan penyidikan dalam rangka mengetahui pemasok narkoba jenis ganja ini di kalangan mahasiswa USU. Toga juga menjelaskan bahwa perbuatan para pelaku dapat dikenakan pasal 114 ayat 1, pasal 111 ayat 1 junto pasal 132 ayat 1 UU No. 35 tahun 2009 tentang Tindak Pidana Narkoba dengan ancaman hukuman penjara seumur hidup atau paling lama 20 tahun. Selain itu, para mahasiswa yang berstatus pemakai atau korban penyalahgunaan akan dilaksanakan asesmen secara medis dan direhabilitasi di kantor BNNP Sumut.

Pihak Kampus USU sendiri ikut menyampaikan bahwa kasus ini akan menjadi catatan dan mengevaluasi seluruh jajaran kampus baik pimpinan, mahasiswa, pihak keamanan, serta masyarakat sekitar lingkungan USU. Oleh karena itu, razia akan dilakukan kedepannya secara rutin sebagai upaya pencegahan tindakan penyalahgunaan narkoba oleh mahasiswa USU. Wakil Rektor 1 USU, Edy Ikhsan mengatakan bahwa untuk sanksi yang akan dijatuhkan sesuai aturan di USU, para

\footnotetext{
13 https://www.realitarakyat.com/2021/10/sebanyak-47-orang-di-usu-diangkut-bnn-sumut-karenaterlibat-narkoba/?print=pdf, diakses pada hari Senin (25/09/21) pada pukul 11.02 WIT

${ }^{14}$ https://regional.kompas.com/read/2021/10/11/192716378/kronologi-bnn-gerebek-fib-usu-3-pengedarganja-ditangkap-31-orang-positif?page=all, diakses pada hari Senin (25/09/21) pada pukul 11.08 WIT
} 
mahasiswa yang terlibat apabila dihukum dengan minimal dua tahun penjara akan mendapatkan sanksi dikeluarkan atau drop out (DO). Selanjutnya, Amalia selaku Kepala Humas USU menambahkan bahwa kasus tersebut telah mencoret citra kampus USU, kemudian mengingatkan kepada para mahasiswa agar tetap mematuhi aturan yang ada dan tidak melanggar hukum baik di dalam maupun di luar kampus.

\section{Hubungan Kasus dengan Teori-Teori Kriminologi}

Kriminologi merupakan ilmu yang memiliki ruang lingkup kajian antara lain; a) orang yang melakukan kejahatan; b) penyebab dilakukannya tindak pidana; c) mencegah kejahatan; dan d) cara merehabilitasi orang yang melakukan kejahatan ${ }^{15}$. Dari pendalaman yang telah penulis lakukan, dapat ditemukan adanya penelitianpenelitian yang berkaitan dengan penyebab terjadinya kejahatan dan alasan hal tersebut dapat bertahan di masyarakat. Berdasarkan kasus yang penulis angkat terkait penyalahgunaan narkoba oleh para mahasiswa FIB USU yang penulis temui berkaitan dengan teori-teori kriminologi. Pada kasus itu terdapat beberapa macam teori kriminologi yang memiliki korelasi dengan studi kasus yang telah dilakukan oleh penulis tentang peredaran dan penyalahgunaan narkoba di kalangan mahasiswa (remaja) berdasarkan pendekatan dan teori-teori kriminologi modern, ${ }^{16}$ sebagai berikut:

\section{a. Social Learning Theory}

Penjelasan Ronald L. Akers dalam Criminological Theories dan "A Social Learning Theory of Crime," teori pembelajaran sosial menyatakan bahwa orang belajar untuk melakukan kejahatan dengan cara yang sama seperti mereka mempelajari hal lain dalam hidup. Selanjutnya, Akers mengambil langkah berikutnya dan mencoba menjelaskan bagaimana pembelajaran itu terjadi dan bagaimana hal itu menghasilkan kejahatan ${ }^{17}$. Teori ini umumnya digunakan dalam menjelaskan penyalahgunaan narkoba terutama dikalangan remaja. Yang menjadi fokus pendekatan dalam tulisan ini adalah dukungan untuk kemampuan teori pembelajaran sosial untuk menjelaskan penyalahgunaan narkoba di kalangan mahasiswa. Pergaulan antar mahasiswa dan teman sebaya merupakan salah satu sumber kuat terjadinya penyalahgunaan narkoba. Diketahui dari pemberitaan diatas bahwa mayoritas pengguna adalah mahasiswa FIB USU. Hal ini dapat disimpulkan bahwa lingkungan sosial yang buruk akan menyebabkan mudahnya proses penyebaran narkoba di kalangan mahasiswa tersebut.

\footnotetext{
${ }^{15}$ Edwin H. Sutherland, Azas-Azas Kriminologi, VII. (Bandung: Alumni, 1969).

${ }^{16}$ KatherineM. Hayes, "Modern Criminology: Crime, Criminal Behavior, and Its Control," Journal of Criminal Justice 14, no. 1 (1986); Jordan Pedalono and Kelly Frailing, "General Strain Theory and Prescription Drug Misuse among Honors Students," Journal of the National Collegiate Honors Council 19, no. 1 (2018).

${ }^{17}$ Ronald L. Akers and Christine S. Sellers, "Social Learning Theory," in The Oxford Handbook of Juvenile Crime and Juvenile Justice, 2011.
} 


\section{b. Differential Association Theory}

Menurut data dari Chicago School, selain dipandang sebagai bagian dari biologi atau sosiologi, kejahatan juga dipandang sebagai bidang sosiologis. Dalam masyarakat modern, bahkan depresi menjadi penyebab sehingga kejahatan dapat muncul dari suatu keadaan, peluang, dan nilai. Singkatnya, teori asosiasi diferensiasi ini memiliki dua versi. Versi pertama disajikan dalam edisi ketiga 'Principle of Criminology' yang menjelaskan aspek-aspeknya sebagai berikut ${ }^{18}$ :

a. Setiap orang akan mengikuti dan menerima pola perilaku yang dapat diterapkan.

b. Kegagalan untuk mengikuti pola perilaku menciptakan inkonsistensi dan ketidakharmonisan.

c. Konflik budaya merupakan prinsip dasar dalam menjelaskan kejahatan.

Kemudian menurut Edwin H. Sutherland, yang menjabarkan versi kedua dari teori ini, mengatakan bahwa semua perilaku dapat dipelajari, artinya tidak ada yang diwariskan dari orang tua. Dalam kasus yang terjadi di FIB USU, alasan para mahasiswa tersebut bisa terjun ke dunia narkoba karena tidak ada warisan dari orang tuanya. Namun timbul dari hatinya untuk menggunakan narkoba karena depresi atau pelarian dari padatnya aktivitas kampus. Dalam proses pengenalan mahasiswa terhadap narkoba, mereka mendapatkan pengaruh dari orang lain yang merupakan mahasiswa juga. Pernyataan mengenai teori ini adalah bahwa teori ini mampu menjelaskan bagaimana siapapun bisa terjerumus suatu tindakan kejahatan termasuk penyalahgunaan narkoba. Dalam hal ini korelasinya dengan para mahasiswa FIB USU adalah semakin lama mereka mengkonsumsi narkoba, ada keinginan untuk terus mencoba yang disebut dengan kecanduan (addicted). Oleh karena itu, para mahasiswa ini akan berusaha untuk terus mencari dan menggunakan narkoba.

\section{c. Labeling Theory}

Dalam teori pelabelan ini membedakan tiga bentuk penyimpangan ${ }^{19}$. Dalam kasus yang diangkat penulis terdapat dua bentuk penyimpangan. Pertama, penyimpangan individu (individual deviation), yaitu penyimpangan yang salah satunya disebabkan oleh tekanan psikologis internal. Hal ini jelas dapat diketahui dari para mahasiswa yang cenderung depresi atau lelah dengan padatnya aktivitas perkuliahan. Yang kedua adalah deviasi situasional (situational deviation), yang merupakan akibat dari stres atau tekanan dari situasi tersebut. Dalam hal ini stress terhadap lingkungan kampus merupakan akibat dari tekanan psikologis yang dialami para mahasiswa. Dalam teori ini juga menjelaskan mengapa seseorang

\footnotetext{
18 A. B. SMUSHKIN, "PRINCIPLES OF CRIMINOLOGY," Actual Problems of Russian Law, no. 5 (2019).

${ }^{19}$ Edwin M. Lemert, Labeling Theory Secondary Deviance, Criminolog. (Routledge, 2015).
} 
diberi label, ada dua aspek yang dikemukakan oleh Howard S. Becker ${ }^{20}$. Yang pertama adalah menjelaskan mengapa dan bagaimana orang-orang tertentu diberi label. Para mahasiswa FIB USU tersebut tentunya dicap sebagai pecandu narkoba oleh beberapa warga karena perbuatannya. Warga menganggap pecandu narkoba hanya bergaul dengan pecandu narkoba. Yang kedua adalah efek label sebagai konsekuensi dari penyimpangan perilaku. Hal ini menyebabkan mahasiswa tersebut menjadi orang yang dijauhi oleh sebagian warga.

\section{d. Anomie /Strain Theory}

Emile Durkheim mendefinisikan teori anomie adalah keadaan dimana tidak adanya norma. Masyarakat pada tempat tersebut tidak mematuhi peraturan atau hukum yang telah diberlakukan di tempat tersebut. Teori ini terbagi menjadi tiga perspektif sebagai berikut: ${ }^{21}$

a. Manusia adalah makhluk sosial;

b. Eksistensi manusia sebagai makhluk sosial;

c. Manusia cenderung hidup bermasyarakat dan keberadaannya sangat bergantung pada hal masyarakat tersebut.

Teori anomie atau strain mengusulkan bahwa ketika masyarakat dicirikan oleh ketidakseimbangan dalam tatanan sosial mereka, itu menciptakan kondisi yang menguntungkan bagi kejahatan dan penyimpangan ${ }^{22}$ seperti penggunaan narkoba. Peraturan perundang-undangan di Indonesia telah mengatur dengan jelas larangan terkait penyalahgunaan narkoba. Namun masih banyak masyarakat yang mengabaikan peraturan tersebut sehingga muncul situasi tanpa norma ${ }^{23}$. Karena sangat jelas bahwa kasus yang dialami para mahasiswa FIB USU tersebut tidak sesuai dengan norma yang ada baik peraturan kampus dan peraturan perundangundangan yang telah diatur.

Berdasarkan pendekatan kasus menggunakan teori-teori kriminologi diatas, banyak para kriminolog mendukung pandangan bahwa lingkungan tempat seseorang dibesarkan akan mempengaruhi peluang mereka untuk melakukan kejahatan. Faktanya, kejahatan dewasa lebih sering terjadi di kalangan remaja dimana mereka mampu memanfaatkan perkembangan teknologi informasi satu sama lain. Faktor sosial sangat mempengaruhi perkembangan kejahatan dalam hal ini penyalahgunaan

\footnotetext{
${ }^{20}$ Howard S. Becker, "Labelling Theory Reconsidered," in Deviance and Social Control, 2018.

${ }^{21} \mathrm{~J}$. Mitchell Miller and Holly Ventura Miller, "Sociological Criminology and Drug Use: A Review of Leading Theories," in The Nurture Versus Biosocial Debate in Criminology: On the Origins of Criminal Behavior and Criminality, 2014.

22 https://soztheo.de/theories-of-crime/anomie-strain-theories/?lang=en, diakses pada hari Rabu (27/09/21) pada pukul 10.49 WIT

${ }^{23}$ M. D. Williams III, F. P., \& McShane, Criminological Theory (Englewood Cliffs: New Jerseyn Printice Hall, 1988).
} 
narkoba di kalangan mahasiswa. Selanjutnya, masih terdapat sejumlah teori lain yang telah dikemukakan namun tidak disertakan dalam tulisan ini.

\section{KESIMPULAN}

Kriminologi dapat didefinisikan sebagai ilmu yang membahas tentang kejahatan yang didalamnya membahas tentang bagaimana suatu kejahatan muncul, bagaimana pola suatu kejahatan, dan juga bagaimana cara penanggulangannya. Tulisan ini mengkaji penggunaan narkoba di kalangan mahasiswa dengan menggunakan teori-teori kriminologi modern. Hasil dari tulisan ini menunjukkan bahwa Social Learning Theory, Labeling Theory, Differential Association Theory, dan Anomie /Strain Theory masih merupakan pendekatan yang kuat dan konsisten dari kemungkinan perilaku penggunaan narkoba mahasiswa atau pelajar. Analisis ini juga menjabarkan sebab penggunaan narkoba para mahasiswa FIB USU tersebut dengan teori modern tentang perilaku menyimpang (deviant) dapat diterapkan atau dapat diterapkan dengan cara yang sama ketika mempertimbangkan tren baru dalam perilaku penggunaan narkoba pelajar zaman sekarang. Namun, teori dan pendekatan kriminologis yang digunakan disini untuk mempelajari studi kasus penggunaan narkoba oleh mahasiswa FIB USU sendiri masih terbatas. Tulisan ini hanya berfokus hanya pada penggunaan narkoba sebagai perilaku menyimpang tanpa mempertimbangkan faktor genetika, epidemiologi, studi kecanduan, dan praktik klinis lainnya dalam rangka pemahaman tentang perilaku penggunaan narkoba secara lebih holistik. Penulis percaya bahwa teori kriminologi diatas sudah cukup penting karena memberikan dasar yang baik untuk memahami kontributor para mahasiswa dan lingkungan (FIB USU) untuk kejahatan tersebut. Tetapi penulis juga percaya bahwa sosiolog dan kriminolog harus bekerjasama menuju pendekatan yang lebih interdisiplin untuk studi kasus penyalahgunaan narkoba pada generasi muda di masa depan.

\section{DAFTAR PUSTAKA}

AKERS, RONALD L. "Social Learning and Social Structure:" Theoretical Criminology 3, no. 4 (1999).

Akers, Ronald L., and Christine S. Sellers. "Social Learning Theory." In The Oxford Handbook of Juvenile Crime and Juvenile Justice, 2011.

Becker, Howard S. "Labelling Theory Reconsidered." In Deviance and Social Control, 2018.

Collins, J. J., \& Messerschmidt, P. M. "Epidemiology of Alcohol-Related Violence." Alcohol Health \& Research World 17, no. 2 (1993): 93-100.

Edwin H. Sutherland. Azas-Azas Kriminologi. VII. Bandung: Alumni, 1969.

Ensminger, Margaret E., James C. Anthony, and Joan McCord. "The Inner City and Drug Use: Initial Findings from an Epidemiological Study." Drug and Alcohol 
Dependence 48, no. 3 (1997).

Fagan, J. "Set and Setting Revisited: Influences of Alcohol and Illicit Drugs on the Social Context of Violent Events." Alcohol and interpersonal violence: fostering multidisciplinary perspectives 24 (1993): 161-191.

Figueira-McDonough, Josefina. " Disorder and Decline: Crime and the Spiral of Decay in American Neighborhoods . Wesley G. Skogan ." Social Service Review 66, no. 2 (1992).

Gorman, D. M. "Etiological Theories and the Primary Prevention of Drug Use." Journal of Drug Issues, 1996.

Hayes, KatherineM. "Modern Criminology: Crime, Criminal Behavior, and Its Control." Journal of Criminal Justice 14, no. 1 (1986).

Khantzian, E. J. “The Self Medication Hypothesis of Addictive Disorders: Focus on Heroin and Cocaine Dependence." American Journal of Psychiatry, 1985.

Lemert, Edwin M. Labeling Theory Secondary Deviance. Criminolog. Routledge, 2015. Lusia Sinta Herindrasti, Valentina. "Drug-Free ASEAN 2025: Tantangan Indonesia Dalam Penanggulangan Penyalahgunaan Narkoba." Jurnal Hubungan Internasional 7, no. 1 (2018).

Mitchell Miller, J., and Holly Ventura Miller. "Sociological Criminology and Drug Use: A Review of Leading Theories." In The Nurture Versus Biosocial Debate in Criminology: On the Origins of Criminal Behavior and Criminality, 2014.

Okada, Dan. "Criminological Theory and Crime Explanation." Criminal Justice and Criminological Paradigms (2015).

Pedalono, Jordan, and Kelly Frailing. "General Strain Theory and Prescription Drug Misuse among Honors Students." Journal of the National Collegiate Honors Council 19, no. 1 (2018).

Sampson, Robert J., Stephen W. Raudenbush, and Felton Earls. "Neighborhoods and Violent Crime: A Multilevel Study of Collective Efficacy." Science 277, no. 5328 (1997).

SMUSHKIN, A. B. "PRINCIPLES OF CRIMINOLOGY." Actual Problems of Russian Law, no. 5 (2019).

White, H. R., J. Brick, and S. Hansell. "A Longitudinal Investigation of Alcohol Use and Aggression in Adolescence." In Journal of Studies on Alcohol. Vol. 54, 1993.

White, H. R. “The Drug Use-Delinquency Connection in Adolescence." In 1990, 215256. Academy of Criminal Justice Sciences: Anderson Publishing Co., 1990.

Williams III, F. P., \& McShane, M. D. Criminological Theory. Englewood Cliffs: New Jerseyn Printice Hall, 1988.

https://regional.kompas.com/read/2021/10/11/192716378/kronologi-bnn-gerebek-fibusu-3-pengedar-ganja-ditangkap-31-orang-positif?page=all, diakses pada hari Senin (25/09/21) pada pukul 11.08 WIT

https://soztheo.de/theories-of-crime/anomie-strain-theories/?lang=en, diakses pada hari Rabu (27/09/21) pada pukul 10.49 WIT 